\title{
Credit granting sorting model for financial organizations
}

\author{
Paulo Cesar Schotten (1), Leydiana de Sousa Pereira and Danielle Costa Morais ${ }^{*}$
}

\section{${ }^{*}$ Correspondence:}

dcmorais@ufpe.org.br

CDSID - Center for Decision

Systems and Information

Development, Universidade

Federal de Pernambuco, Av.

Acadêmico Hélio Ramos, s/n

- Cidade Universitária, Recife,

PE CEP 50.740-530, Brazil

\begin{abstract}
Considering the environment of risks and influences inherent in the decision-making process for credit-granting operations, it has become a matter of survival for financial organizations to seek to improve how they engage in effective decision-making to ensure that their returns on invested capital will meet the expectations established at the beginning of the process. A credit-granting sorting model for financial organizations is proposed. The model aggregates the perspectives of different decision-makers to support an organization in the process of credit analysis and, consequently, to improve its operationality. The decision-making model is based on the ELECTRE TRI-B multicriteria method. It sorts credit-granting proposals into three classes, namely credit approved, technical analysis, and credit rejected. The group decision emerges from the decision rules of the organization's executive board. This new proposed approach to dealing with credit-granting results in the systematization of credit analysis, reduction of doubt among decision-makers, avoidance of the emergence of informal groups, reduction of conflicts within a financial organization, and external interferences.
\end{abstract}

Keywords: Credit granting, ELECTRE TRI-B, Financial market, Group decision-making, Multicriteria methods

\section{Introduction}

The decision-making process is fundamental for organizations, especially those that deal with a risk environment. Studies on the decision-making processes of such organizations generate theoretical gains, thus expanding knowledge about decisionmaking, and aiding the development of new methodologies to improve organizational practices (Baucells and Sarin 2003; Zavadskas and Turskis 2011; Schäfermeyer et al. 2012; Roy and Slowiński 2013; Zopounidis and Doumpos 2013; Saaty 2013; Ulucan and Atici 2013; Doumpos and Figueira 2019; Schotten and Morais 2019; Gaganis et al. 2020). Strategically, financial organizations whose purpose is to develop the market must strive to minimize operational errors while remaining aware that the main threat for banks and financial institutions, according to Marqués et al. (2013), arises from the difficulty in distinguishing creditworthy candidates from those who are unlikely to repay loans. Credit decisions in financial organizations are also subject to uncertain environments, depending on several external factors, mainly the author(s) and the source, provide a link to the Creative Commons licence, and indicate if changes were made. The images or other third party material in this article are included in the article's Creative Commons licence, unless indicated otherwise in a credit line to the material. If material is not included in the article's Creative Commons licence and your intended use is not permitted by statutory regulation or exceeds the permitted use, you will need to obtain permission directly from the copyright holder. To view a copy of this licence, visit http:// creativecommons.org/licenses/by/4.0/. 
population's economic and social conditions (Cleofas-Sánchez et al. 2016; Palazuelos et al. 2018; Kautonen et al. 2020; Palazuelos et al. 2020).

The standardization of the decision-making process can minimize the influence of changes in the financial environment, and the adoption of decision-making models can be a standardization tool (Schäfermeyer et al. 2012; García et al. 2019). Schotten and Morais (2019) argue that the decision-making process of financial entities requires continuous assessment and must systematically meet their expectations. In addition, these authors point out that credit operations involve significant risks, and the decisions made by a group are not limited to the consideration of a single individual but rather the perceptions of many people who, after having been prepared to participate in the process, can contribute to the depth of the analysis and exert greater assertiveness.

The group decision process has many important aspects that must be considered, one of which is the need for information. When the demand for data is latent and requires the participation of many decision-makers (DMs), the results obtained can reflect organizational competitiveness. The objective of making a decision that reflects a high level of quality must be dealt with creatively, and obstacles to communication must be removed. Using a system capable of transmitting the necessary information contributes to facilitating the group decision-making process (Bohanec 2009).

The process flow must also be considered in group decisions. Tsoury et al. (2019) state that business process management offers organizations the operational benefits of reducing costs, increasing the speed of response, and improving the quality of products and services, thus highlighting the advantages of the information systems supported by such a flow. The authors also note that data flow analysis and modeling ensure the complete and accurate design of business processes.

Managing credit-granting processes is critical to the success of a financial organization's operations. Addressing the challenges of identifying, measuring, and mitigating credit-granting errors is part of this management process. The development of a decision-making model for financial organizations that are linked to their strategic organizational goals is fundamental for survival in the market.

The main difficulty in credit management is to decide which proposals will be granted. Therefore, this paper puts forward a decision-making model to sort each proposal into previously defined classes. Thus, this article presents a sorting model based on the ELECTRE TRI-B multicriteria method, which serves as an evaluation tool for facilitating financial organizations' credit-granting processes. It is an adequate method for assigning alternatives to pre-defined ordered categories. This method presents certain advantages: the definition of the limits of categories is preliminary; the criteria scales can be qualitative or quantitative; different sets of criterion weights can be accepted; and data normalization is not necessary.

Due to the influences of and pressures experienced by DMs and the risks inherent in loan operations, the proposed model recommends the participation of more than one DM. Therefore, a group of aggregation parameters is set to determine the final classification of a proposal. One of the characteristics of the proposed model is its flexibility. Any organization that deals with group credit analysis in the financial system can use it. For application in other organizations, criteria for analysis, weights, and preferences should 
be defined according to their strategic organizational objectives. For example, the proposed model is applied in a real case in a credit organization located in Brazil.

This article is divided into five sections including this introduction (which has presented the objective of the article and the justification for developing a sorting model for financial organizations). In "Related studies" section discusses related studies that guide this article and contribute to the design and formatting of the model, thereby addressing aspects related to the organizational strategy, credit-granting environment, and models that are used to understand the decision-making process. In "New approach to the credit analysis process in an organization" section presents the case study that was undertaken to understand the credit analysis process more completely. In "Preliminary analysis" section presents the decision-making model for financial organizations and demonstrates the concept of the model, the flow of development, and aggregation for a group decision. In "Discussion and conclusion" section discusses the results and presents the practical and theoretical implications of the study.

\section{Related studies}

All organizations seek to consolidate and improve their position in the market and ensure their survival in the long term. To face risks, uncertainties, and turbulence successfully, organizations need to establish strategies that safely guide how they pursue their goals. When applied to management, these strategies promote rationality and a vision of the future that drives the entire management process, which includes defining the management tools they need to make rational decisions.

The concern about how strategies should be applied considering the influence and rationality of the organizational decision-making process has been the object of studies already carried out, and an overview of these is given in Table 1. These studies focus on understanding how environmental and rational aspects are interconnected and how they influence the decision-making process and a DM's behavior. As shown in Table 1, the main contributions are the concern with the rationality of the process, the vision of the future, and the consequences of the decision concerning the strategic objectives of an organization.

Cabrerizo et al. (2013) define group decision-making (GDM) as a problem in which several DMs provide their judgments about a set of alternatives, the aim of which is to obtain different aggregate preferences from individuals to find an alternative (or set of alternatives) that is more acceptable to the group as a whole.

A methodology for making group decisions contributes rationally to this strategic management process. It allows DMs to become aware of the uncertainties and risks inherent in the credit-granting process and become mindful of the influences under which this process is subjected. As it is a strategic process, it helps DMs to consider the consequences of their decisions, and this leads them to consider the impact of these on their organization's strategic objectives. The related studies are presented in Table 2 . The contributions of these studies come from the operational and environmental view of the financial market, from contextualizing risks, and from assessing the influence of this environment in decision-making.

Understanding the financial environment, borrowers' behavior, and the behavior of loan-granting organizations helps to have a comprehensive view of operations, thus 
Table 1 Strategic concepts that guided the decision-making model

\begin{tabular}{|c|c|c|}
\hline Author & Study objective & Contribution \\
\hline Nutt (1998) & $\begin{array}{l}\text { Explored the uncertainty of DMs in } \\
\text { the process of evaluating alternatives }\end{array}$ & $\begin{array}{l}\text { The concern with a rational model that } \\
\text { guides the DM }\end{array}$ \\
\hline Zopounidis and Dimitras (1998) & $\begin{array}{l}\text { Presented a study addressing the } \\
\text { ELECTRE TRI Method and predicting } \\
\text { business failure }\end{array}$ & $\begin{array}{l}\text { Defended the idea of applying the } \\
\text { method to find organizational solutions }\end{array}$ \\
\hline Høyland and Wallace (2001) & $\begin{array}{l}\text { Presented the need to build scenarios } \\
\text { for decision-making in multiple } \\
\text { stages and environments under } \\
\text { uncertain conditions }\end{array}$ & $\begin{array}{l}\text { Concern about the future and the } \\
\text { consequences of the decision }\end{array}$ \\
\hline Elbanna and Child (2007) & $\begin{array}{l}\text { Approached the strategic angle with } \\
\text { a study on strategic rationality in } \\
\text { decision-making }\end{array}$ & $\begin{array}{l}\text { They studied the importance of ration- } \\
\text { ality in decision-making processes }\end{array}$ \\
\hline Hwang and Lin (2012) & $\begin{array}{l}\text { Group decision making under multi- } \\
\text { ple criteria }\end{array}$ & $\begin{array}{l}\text { Developed a study on multicriteria } \\
\text { methods and applications in group } \\
\text { decisions }\end{array}$ \\
\hline Garrido et al. (2014) & $\begin{array}{l}\text { Offered a detailed analysis of the } \\
\text { primary measures that have been } \\
\text { used by institutions in previous work } \\
\text { on strategic management }\end{array}$ & $\begin{array}{l}\text { Studied strategic management meas- } \\
\text { ures and their application in decision- } \\
\text { making }\end{array}$ \\
\hline Guerras-Martín et al. (2014) & $\begin{array}{l}\text { Explored the evolution of strategic } \\
\text { management research }\end{array}$ & $\begin{array}{l}\text { They highlighted the evolution and } \\
\text { importance of studying strategic } \\
\text { management }\end{array}$ \\
\hline Chavira et al. (2017) & $\begin{array}{l}\text { ELECTRE-III method and a multiobjec- } \\
\text { tive evolutionary algorithm }\end{array}$ & $\begin{array}{l}\text { Developed a credit ranking model for a } \\
\text { financial company }\end{array}$ \\
\hline Pérez et al (2018) & Group decision process & $\begin{array}{l}\text { Studies on dynamic consensus } \\
\text { processes in group decision-making } \\
\text { problems }\end{array}$ \\
\hline Khraisha and Arthur (2018) & $\begin{array}{l}\text { Examines the hypothesis of a general } \\
\text { theory that encompasses increasing } \\
\text { complexities in the financial innova- } \\
\text { tion process }\end{array}$ & $\begin{array}{l}\text { Focus on the innovation process and } \\
\text { complexity of the financial sector }\end{array}$ \\
\hline
\end{tabular}

permitting the development of a decision-making model that meets an organization's needs and protects the process. When commenting on safeguarding the process, any methodology developed must anticipate some specific factors concerning strategic management. In this case, organizations should be discussed in terms of credit security, as their objective when granting a loan is to recover, over time, the capital invested. Obtaining the return for this capital, together with interest and fees, helps a financial organization to achieve its strategic objectives; otherwise, operations can become unstable.

Another point that must be considered regarding the methodology is the DM's behavior; that is, the person who undertakes the credit analysis. The organization must provide the DM with sufficient tools and guidance so that he or she feels secure in this process, leading him or her to consider the consequences of his or her decision concerning the set of strategic objectives. The tool applied must enable the DM to view the management policies, the risks and uncertainties in the environment, and the influences and pressures on the system operators, and to verify conformity with corporate governance.

As the decision-making model for this study was based on multicriteria classification, its development was inspired by the studies of the models (and inferences from them) presented in Table 3. Studies that focused on information technology were also considered a point of reference for developing and guiding the formatting of this model. 
Table 2 Summary of studies on the credit-granting environment, the risks involved, and financial operations

\begin{tabular}{|c|c|c|}
\hline Author & Study objective & Contribution \\
\hline Zopounidis and Doumpos (2002) & $\begin{array}{l}\text { Demonstrated a wide range of mul- } \\
\text { ticriteria judgment-based method- } \\
\text { ologies and their applications in the } \\
\text { real world }\end{array}$ & $\begin{array}{l}\text { Applications of multicriteria method- } \\
\text { ologies in financial decisions }\end{array}$ \\
\hline Parrino et al. (2005) & $\begin{array}{l}\text { Explored the effect of operational } \\
\text { risk on financial decisions, creating a } \\
\text { model for making corporate invest- } \\
\text { ment decisions }\end{array}$ & $\begin{array}{l}\text { Created an investment decision-mak- } \\
\text { ing model, considering the opera- } \\
\text { tional risk in financial decisions }\end{array}$ \\
\hline Doumpos and Zopounidis (2010) & $\begin{array}{l}\text { Explored the role of banks and } \\
\text { financial institutions in the economic } \\
\text { and business environment, consider- } \\
\text { ing the high level of risk to which } \\
\text { financial institutions are exposed }\end{array}$ & $\begin{array}{l}\text { Study of the role of financial organiza- } \\
\text { tions considering the risk of the } \\
\text { environment }\end{array}$ \\
\hline Garcia et al. (2013) & $\begin{array}{l}\text { Explored credit risks and bad debt, } \\
\text { a variable for classifying customers } \\
\text { when decisions need to be made }\end{array}$ & $\begin{array}{l}\text { Studied the classification of customers } \\
\text { considering credit and default risks }\end{array}$ \\
\hline Zopounidis et al. (2015) & $\begin{array}{l}\text { Multiple criteria decision aiding for } \\
\text { finance }\end{array}$ & $\begin{array}{l}\text { Developed a bibliographic survey on } \\
\text { decision support for multiple criteria } \\
\text { for finance }\end{array}$ \\
\hline Kashig et al. (2016) & $\begin{array}{l}\text { Investigated the loan growth and } \\
\text { risk-taking behavior of banks during } \\
\text { expansionary periods of lending }\end{array}$ & $\begin{array}{l}\text { Studied credit risk in periods of loan } \\
\text { expansion }\end{array}$ \\
\hline Spronk et al. (2016) & $\begin{array}{l}\text { Studies concerning Multicriteria } \\
\text { Decision Aid/Analysis in Finance }\end{array}$ & $\begin{array}{l}\text { Contributed to studies on the applica- } \\
\text { tion of the multicriteria methodology } \\
\text { in financial management }\end{array}$ \\
\hline Arthur (2017) & $\begin{array}{l}\text { Investigated how two major financial } \\
\text { innovations occurred and were gov- } \\
\text { erned, and it discusses the findings } \\
\text { concerning those in the literature }\end{array}$ & $\begin{array}{l}\text { Outlined the study of financial innova- } \\
\text { tion }\end{array}$ \\
\hline Hamdi et al. (2017) & $\begin{array}{l}\text { Test factors that determine the level } \\
\text { of non-interest income for Tunisian } \\
\text { banks; studied the impact of non- } \\
\text { interest income on banks' profit- } \\
\text { ability measured by return on assets } \\
\text { (ROA) and return on equity (ROE) } \\
\text { and investigated the relationship } \\
\text { between non-interest income and } \\
\text { the level of risk-taking }\end{array}$ & $\begin{array}{l}\text { In their studies, they demonstrated a } \\
\text { relationship between diversification, } \\
\text { performance and risks }\end{array}$ \\
\hline Koksalmis and Kabak (2019) & $\begin{array}{l}\text { Defining weights in group decision } \\
\text { making }\end{array}$ & $\begin{array}{l}\text { Contributes in exemplification to } \\
\text { derive weights from decision-makers } \\
\text { in group decision making }\end{array}$ \\
\hline Rehman et al. (2019) & $\begin{array}{l}\text { Identified risk management strate- } \\
\text { gies that are undertaken by the } \\
\text { commercial banks of Balochistan, } \\
\text { Pakistan, to mitigate or eliminate } \\
\text { credit risk }\end{array}$ & $\begin{array}{l}\text { Studied risk management strategy to } \\
\text { eliminate the risk of granting credit }\end{array}$ \\
\hline Klapper and Lusardi (2019) & $\begin{array}{l}\text { Examined basic financial concepts } \\
\text { and decisions related to financial } \\
\text { management }\end{array}$ & $\begin{array}{l}\text { Exploration of decision-making and } \\
\text { credit risks }\end{array}$ \\
\hline Marqués et al. (2020) & $\begin{array}{l}\text { Ranking-based MCDM models in } \\
\text { financial management applications }\end{array}$ & $\begin{array}{l}\text { Applications of multicriteria models in } \\
\text { financial management }\end{array}$ \\
\hline Pla-Santamaria et al. (2020) & $\begin{array}{l}\text { Study on risk management and } \\
\text { uncertainty environments }\end{array}$ & $\begin{array}{l}\text { Developed a multicriteria approach } \\
\text { to manage credit risk under strict } \\
\text { uncertainty }\end{array}$ \\
\hline Shen et al. (2020) & $\begin{array}{l}\text { Proposes a novel three-stage reject } \\
\text { inference learning framework using } \\
\text { unsupervised transfer learning and } \\
\text { three-way decision theory that } \\
\text { integrates }\end{array}$ & $\begin{array}{l}\text { Method for credit risk management } \\
\text { applications }\end{array}$ \\
\hline
\end{tabular}


Table 2 (continued)

\begin{tabular}{lll}
\hline Author & Study objective & Contribution \\
\hline Kou et al. (2021) & $\begin{array}{l}\text { Studied the bankruptcy prediction } \\
\text { for SMEs using transactional data } \\
\text { and two-stage multiobjective feature } \\
\text { selection }\end{array}$ & $\begin{array}{l}\text { Presents model that studied the risk } \\
\text { and prediction of bankruptcy }\end{array}$ \\
Wang et al. (2021) & $\begin{array}{l}\text { Modeling Multi-class misclassifica- } \\
\text { tion cost matrix for credit ratings in } \\
\text { peer-to-peer lending }\end{array}$ & Modeling for credit rating \\
\hline
\end{tabular}

The decision-making process of an organization is based on a sorting model because the objective is to divide the proposals that are received into those that can be approved, those that cannot be approved, and those that deserve special attention-in this case, an in-depth analysis by a credit specialist.

With regard to the approaches related to the strategic design of the decision that must be made (Table 1) and the environment and operations in which financial organizations are embedded (Table 2), understanding these approaches leads to developing a strategic vision for granting credit based on a multicriteria decision for ordering, selecting, sorting, or describing alternatives within a decision-making process involving multiple criteria.

It then follows that the decision-making model to be adopted in the credit-granting process of a financial organization must consider its strategic concepts and organizational environment. Consequently, considering the set of advantages based on models that have already been developed (as presented in Table 3), this study proposes a multicriteria sorting model for decision-making.

The models presented were developed for various purposes. These indirectly link multiple types of knowledge to each other that should be considered when constructing a credit-granting model for financial organizations. This knowledge comes from conceptualizing the functionality of the group's decision process, as it is applied to other purposes, and recognizing how it can be used for the process of granting credit. It is worth mentioning that the methodologies discussed imply knowledge about factors such as an organization's setting, decision-making models, sorting models, group behaviors, critical criteria, and ways of dealing with uncertainties and risks, and the application of information technology to decision-making processes.

To develop the model presented in this paper, since it is a sorting problem, the Electre TRI-B method was adopted. The ELECTRE TRI method was presented by Mousseau et al. (2000) as a multicriteria classification method that assigns alternatives to pre-defined categories. The assignment of an alternative is the result of comparing it with the limits that define a predefined category. More information about the Electre TRI-B method is presented in the development of this method, and it is recommended that the following studies be consulted: Roy and Bouyssou (1993), Mousseau and Slowinski (1999), Mousseau et al. (2000), Rigopoulos and Anagnostopoulos (2010), Zheng et al. (2014), Bouyssou and Marchant (2015), Govindan and Jepsen (2016), Corrente et al. (2017), Dias and Mousseau (2018) and Kadzinki and Martyn (2020). 
Table 3 Synthesis of models studied to understand the decision-making process

\begin{tabular}{|c|c|c|}
\hline Author & Study objective & Contribution \\
\hline Baucells and Sarin (2003) & $\begin{array}{l}\text { Focused on group decisions in } \\
\text { which individuals or committees } \\
\text { share the responsibility for choosing } \\
\text { between alternative proposals for } \\
\text { action }\end{array}$ & Group decision model \\
\hline Hochbaum and Levin (2006) & $\begin{array}{l}\text { Conducted classification method } \\
\text { reviews }\end{array}$ & Sorting model \\
\hline Doumpos and Zopounidis (2010) & $\begin{array}{l}\text { Developed a Decision Support } \\
\text { System based on several criteria to } \\
\text { measure financial risks in banking } \\
\text { institutions }\end{array}$ & Multicriteria decision support systems \\
\hline Zopounidis and Doumpos (2013) & $\begin{array}{l}\text { Conducted portfolio selection and } \\
\text { corporate performance evaluation } \\
\text { using various approaches to multicri- } \\
\text { teria modeling tools }\end{array}$ & Multicriteria decision models \\
\hline Figueira et al. (2013) & $\begin{array}{l}\text { Studied about ELECTRE methods } \\
\text { and their recent extensions }\end{array}$ & $\begin{array}{l}\text { Presented an overview of ELECTRE } \\
\text { methods and their recent extensions }\end{array}$ \\
\hline Saaty (2013) & $\begin{array}{l}\text { Explored decision factors and judg- } \\
\text { ments by DMs }\end{array}$ & $\begin{array}{l}\text { Decision-making model and meth- } \\
\text { odology }\end{array}$ \\
\hline Ulucan and Atici (2013) & $\begin{array}{l}\text { Developed an approach to classify- } \\
\text { ing problems that deal with more } \\
\text { than one classification criterion } \\
\text { involving multiple alternatives }\end{array}$ & Sorting model \\
\hline Lin et al. (2015) & $\begin{array}{l}\text { Investigate primary innovative } \\
\text { Internet-based financial services }\end{array}$ & Financial services \\
\hline Zhang et al. (2015) & $\begin{array}{l}\text { Developed a credit risk assessment } \\
\text { model based on SVM for small and } \\
\text { medium enterprises in supply chain } \\
\text { finance }\end{array}$ & Credit risk assessment model \\
\hline Pérez-Aróstegui et al. (2015) & $\begin{array}{l}\text { Explored the relationship between } \\
\text { information technology (IT) compe- } \\
\text { tence and quality management }\end{array}$ & $\begin{array}{l}\text { Contextualization of IT in the decision- } \\
\text { making process }\end{array}$ \\
\hline Angilella and Mazzù (2015) & $\begin{array}{l}\text { Used multicriteria decision-making } \\
\text { methods and conducted a credit-risk } \\
\text { analysis with the help of ELECTRE } \\
\text { TRI-B methods }\end{array}$ & Decision-making methodology \\
\hline Wu and Kou (2016) & $\begin{array}{l}\text { A consensus model for Group } \\
\text { Decision-Making (GDM) }\end{array}$ & Decision-making method \\
\hline Asongu and Nwachukwu (2017) & $\begin{array}{l}\text { Investigated how an increase in } \\
\text { information-sharing bureaus affects } \\
\text { financial access }\end{array}$ & Information \\
\hline Chen et al. (2017) & $\begin{array}{l}\text { The development of Financial } \\
\text { Technology (FinTech) in areas such } \\
\text { as mobile Internet, cloud comput- } \\
\text { ing, big data, search engines, and } \\
\text { blockchain technology }\end{array}$ & Financial Technology \\
\hline Alhassany and Faisal (2018) & $\begin{array}{l}\text { They examined how the decision } \\
\text { to adopt internet banking in North } \\
\text { Cyprus would be affected based } \\
\text { on the following dimensions: the } \\
\text { technology features, the personal } \\
\text { characteristics, the social environ- } \\
\text { ment, and the expected risk }\end{array}$ & Information technology \\
\hline Moradi and Rafiei (2019) & $\begin{array}{l}\text { Presented a model that is both more } \\
\text { flexible to politico-economic factors } \\
\text { and can yield results that are max } \\
\text { compatible with real-life situations }\end{array}$ & Credit risk assessment model \\
\hline Guo et al. (2019) & $\begin{array}{l}\text { Developed a decision-aid approach } \\
\text { to risk classification problems }\end{array}$ & Risk classification and decision model \\
\hline
\end{tabular}


Table 3 (continued)

\begin{tabular}{lll}
\hline Author & Study objective & Contribution \\
\hline Çalı and Balaman (2019) & $\begin{array}{l}\text { Developed a group decision-making } \\
\text { methodology for solving problems } \\
\text { efficiently under uncertain condi- } \\
\text { tions }\end{array}$ & Uncertainty/decision methodologies \\
Doumpos and Figueira (2019) & $\begin{array}{l}\text { Used the ELECTRE TRI-nC method to } \\
\text { build internal credit-rating models } \\
\text { with a judgment structure based on } \\
\text { a credit specialist's evaluations } \\
\text { Developed a multicriteria decision }\end{array}$ & $\begin{array}{l}\text { Multicriteria decision-making meth- } \\
\text { odology }\end{array}$ \\
Gaganis et al. (2020) & Multicriteria decision model \\
& ment process of operations & \\
\hline
\end{tabular}

\section{New approach to the credit analysis process in an organization}

This section presents the proposed model for group decision making in the credit analysis process in financial organizations. The model considers the operational flow from the entry of the credit proposal, alternatives to be evaluated, definitions of evaluation criteria, weights of criteria, the definition of classes, aggregation processes for group decision, and the result of the evaluation process. The development process of the model and its methodological explanations are identified in each part developed and described in this section.

\section{Concept of the model}

The proposed model aims to meet the operational needs of financial organizations that apply or intend to adopt a group decision approach to granting credit. The model's objective is to serve as a tool for decision-making, following strategic precepts. It can be applied to all types of organizations for analysis and credit granting.

The model's strategic core that should define the alternatives, criteria, weights, and decision rules must be approved by the Chief Executive Officer (CEO) or another senior officer responsible for the strategic results of the organization. DMs must be chosen and prepared to use the model and the number (n) of such DMs can be related to the needs proposed by the organization. To meet the needs and parameters defined by the model, a minimum of two DMs is necessary, all of whom have the same importance in the process. The flow of analysis for each credit proposal follows the paths shown in Fig. 1.

As Fig. 1 shows, the service unit first analyzes the proposed flow when the proposal is received in terms of its eligibility for consideration, and subsequently forwards it to the DMs. The DMs analyze the proposal according to the strategic objectives and directions presented by the organization and score each criterion, leading to a result that, once tabulated, will yield one of the following decisions: approved; forward to technical analysis; or rejected. The DMs' preferences need to be aggregated by decision rules. If approved, the proposal is returned to the branch for credit release. If rejected, it is returned to the branch to be reformulated, or the client is notified of non-approval. If necessary, the proposal is submitted for technical analysis, where a specialist will perform an individual analysis of the proposal and may approve or reject it, and the decision follows the normal flow already presented. 


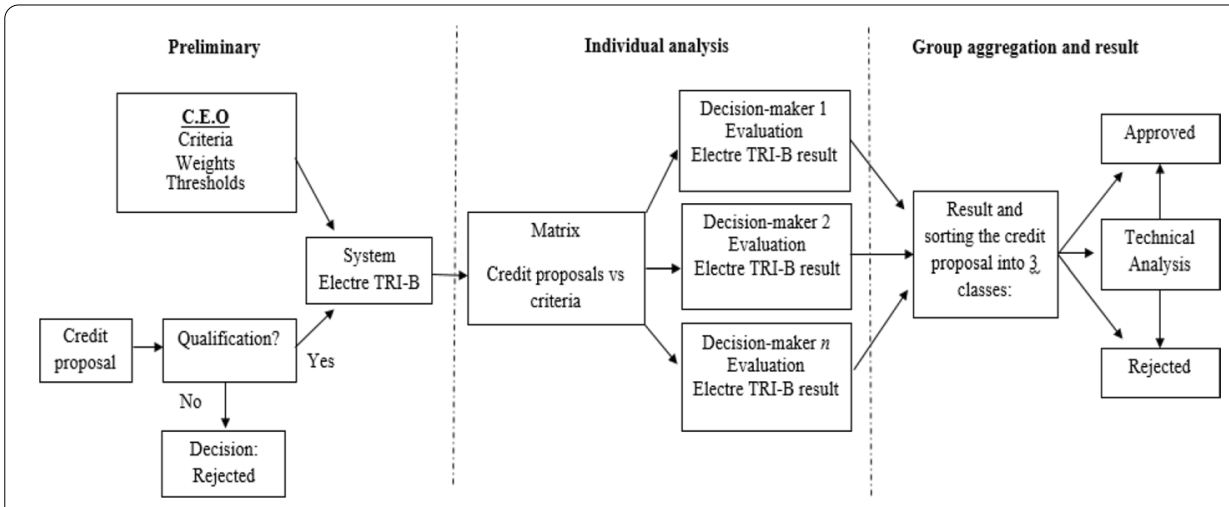

Fig. 1 The operational flow of the proposed approach

\section{Credit analysis process: a case study}

The organization that was used in this study is a credit cooperative of free admission of associates, located in Brazil. This type of credit union, although formed by regional cells, each with some autonomy and specific procedures such as the process of credit analysis, follows norms established by a central unit. The credit decision process adopted by focusing on credit analysis is, internally, called the Electronic Decision Process. This process consists of several steps until a final analysis is conclusive. The current method of credit decision goes through some stages from the initial proposal until, when appropriate, it goes through a committee specially created for this purpose. The studied organization works with three levels of credit analysis. First is individual authority, which refers to the autonomy of the service unit manager who can analyze and decide whether or not to approve credit. Credit proposals, the value of which does not exceed R $\$ 15,000.00$ (approximately US\$ 3000) fall into this category. Proposals with a value of between $R$ \$ 15,000.00 and R\$ 200,000.00 (approximately U\$ 40,000) are analyzed by a committee comprising three people. The model in this study was developed to help such a committee reach a group decision. Figure 1 shows the flow that the model follows. Proposals with values greater than $\mathrm{R} \$ 200,000.00$ are considered special credits and are now analyzed and require the Executive Director's approval.

The core of the committee is the group consisting of three people appointed by the executive board, who analyze the proposal and, from this analysis, can approve or reject the application for the credit. The rule established for the committee's analysis is that for a proposal to be approved, the decision should be unanimous, that is, all members of the committee should vote favorably on the proposal presented. Based on the decision of the organizational managers, all the DMs have the same degree of importance in the vote.

The committee of DMs receives the process electronically, which comprises a preliminary opinion drafted by officials who occupy positions within the branch and proceed to analyze it. The proponent's current financial status and financial capacity, a market analysis, the relationship and management of the accounts, a review of its strengths and weaknesses, and a conclusion, represented by the considerations of the proponent's account manager, are set out in the opinion. The decision-making is based directly on the reports provided by the system, indicated as the register of the borrower and the 
guarantors, exposure to the financial credit system, the cash flow of the physical or legal tenderer, and, finally, of the operation.

The DM's role in receiving the process is to analyze the documentation and, through the system, to vote in favor or against the process. The system automatically shows the aggregate result of the three DMs. The decision-making process of the organization is a group decision process, which follows the rules regarding the legality and operability of the process. Some problems are generators of insecurities, which may even have an adverse effect on achieving strategic organizational objectives. The main problems detected in the analysis were:

- A DM's insecurity: The lack of a systematic process makes it challenging to analyze the strategic consequences, since the DM acts only based on his/her perception or knowledge that he/she has about the proposer, thus increasing the risk of the operation.

- Emergence of informal groups: Although not proposed in the flow chart of the decision-making process, members may meet informally to discuss the process under review, directing the decision against the will of the member with the highest decision-making power or most significant influence within the group. The organization has no control over these informal meetings.

- Conflicts during the process: These can occur during the contact between the proposer and the branch. Another point of conflict is the relationship among the committee members. Conflicts can arise due to the delay in the process or dissatisfaction with the result of the analysis.

- Possibility of corruption and collusion among the members of the committee: The proximity and frequent contact between members can lead to the formation of shadowy interest groups, not linked to strategic organizational objectives but to benefit people or groups with external interests.

- Interference during the process: This is a critical point where external pressure from members of the committee with higher decision-making power in the hierarchy of the financial organization itself or members outside the committee can occur during the analysis.

The origin of the problems presented is in how the process was designed. The DM receives the process and classifies it as "approved" or "not approved," without specific guidance, and this is based only on the subjectivity of his/her perception. The model developed and presented in the next section seeks to eliminate or at least reduce the problems in the decision process detected in the current method adopted by the organization under study.

\section{Preliminary analysis}

\section{Credit proposal inputs (alternatives)}

The decision-making model is based on the emergence of decision alternatives. In this case, the alternatives are individual; that is, each proposal for credit granting is considered an alternative. The analysis aims to identify whether the proposal should be approved, forwarded for technical analysis, or rejected by comparing it with the 
organization's specifications. The alternatives (proposals) will be analyzed within the model, guided by the CEO's previously defined criteria, considering strategies and organizational objectives.

Once the proposal is entered into the system, the service unit makes an initial analysis of the proposal, aiming to determine whether it meets the company's regulations for granting credit. If the proposal receives a favorable opinion, it will follow the credit analysis flow presented in Fig. 1. If the proposal receives an unfavorable opinion regarding its suitability, it is automatically rejected. In the case study, 12 credit proposals (alternatives) were considered for analysis.

\section{Definition of criteria}

The establishment of decision-making criteria involves strategic decisions, and in this case, these criteria may vary between organizations. The CEO determines which criteria to consider when assessing credit granting. For the specific purposes of developing this model, a workshop was used in choosing the criteria. Based on the organizational strategies and ownership of the analysis process currently adopted in the organization, the CEO described the criteria that were important to him in the analysis. Then, he called the Credit Analysis Technician to give an opinion on the criteria chosen. After a brief discussion, we defined the criteria to be adopted in the process presented in Table 4. Importantly, this process of determining the criteria is one of the flexible parts of the model and, in the eventual application in other organizations, may be defined as new criteria to meet the strategic needs of the organization to which the model is being applied.

To establish the importance and weight of each criterion, we adopted the revised Simos' procedure presented by Figueira and Roy (2002). As part of the procedure, cards are given to the CEO, each relating to one of the criteria defined, and the CEO

Table 4 Criteria for analysis

\begin{tabular}{ll}
\hline Criteria/code & Description \\
\hline Payment capacity: PCP & $\begin{array}{l}\text { Analysis of the maximum payment limit (instalment) to be assimilated by the } \\
\text { proponent's income, considering all other primary individual and family needs of } \\
\text { the proponent }\end{array}$ \\
Financial score: FSC & $\begin{array}{l}\text { Analysis of the financial results presented in the Balanced Scorecard and the evalu- } \\
\text { ations of the Central Bank }\end{array}$ \\
Debt capacity: DCP & $\begin{array}{l}\text { Financial limit of values that may be assumed according to the company's finan- } \\
\text { cial, history and turnover }\end{array}$ \\
Operations history: OPH & $\begin{array}{l}\text { Internal analysis of previous operations of the proponent that characterizes the } \\
\text { proponent as an excellent or poor payer, and level of delay }\end{array}$ \\
Warranty in operation: WOP & $\begin{array}{l}\text { Existence of assets in guarantee and guarantor that will assume joint and sequen- } \\
\text { tial responsibility for the amount in case of default by the proponent } \\
\text { Wealth analysis: WAN }\end{array} \quad \begin{array}{l}\text { Analysis of the equity presented that can meet the commitments assumed by the } \\
\text { proposer } \\
\text { Verification of the professional activity of the proponent concerning stability and } \\
\text { risk and variations in profits } \\
\text { Internal analysis of the personal relationships of the proposer with the organiza- } \\
\text { tion, active participation in committees, assemblies, personal knowledge of the } \\
\text { board, and agency }\end{array}$ \\
\hline
\end{tabular}


Table 5 Importance and weight of the criteria

\begin{tabular}{lll}
\hline Criteria/code & Description & $\begin{array}{l}\text { Normalized } \\
\text { weight }\end{array}$ \\
\hline WAN & Wealth analysis & 7.14 \\
PAC & Professional activity & 7.14 \\
REL & Relationship level & 7.14 \\
FSC & Financial score & 14.29 \\
DCP & Debt capacity & 14.29 \\
OPH & Operations history & 14.29 \\
WOP & Warranty in operation & 14.29 \\
PCP & Payment capacity & 21.42 \\
& & 100 \\
\hline
\end{tabular}

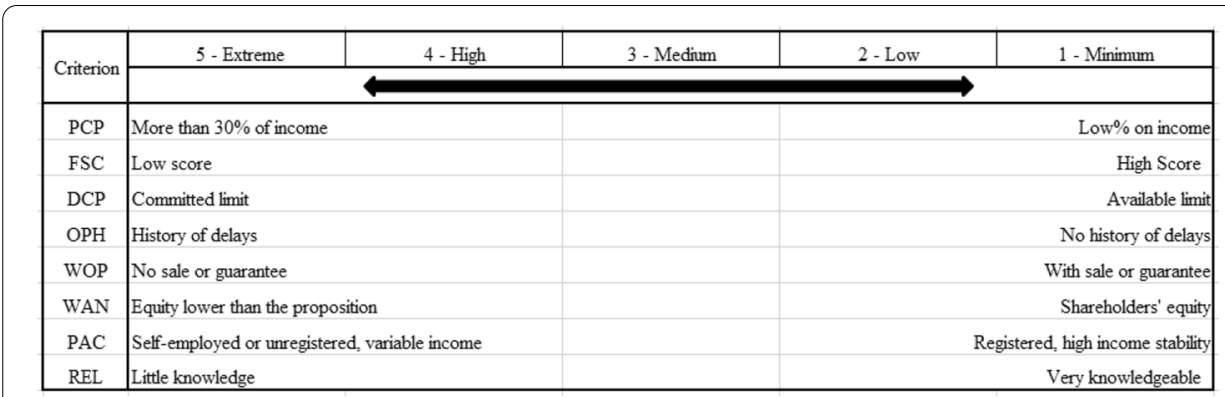

Fig. 2 Continuum of the characteristics of the scales

is requested to arrange the cards in the order of importance. After this, the CEO must be given white cards that he should insert between the criteria cards, where the CEO considers that there is a significant difference between one criterion and another.

Then, the criteria of equal importance are grouped into specific positions. Normalized weights are obtained by applying the method proposed in the approach. The SRF (Simos-Roy-Figueira) software suggested and presented by Figueira and Roy (2002) was used for calculating weights. The normalized weight for each criterion is shown in Table 5 .

\section{Scale definition}

After defining the weights of the criteria, it is necessary to define an evaluation scale. For the proposed model, an ordinal classification was adopted, defined by Dembczynski et al. (2007) as a set of values for the decision attribute (output, dependent variable) that is finite and ordered. A five-point scale was designed to guide the DM's analysis: 5Extreme danger; 4-High risk; 3-Medium risk; 2-Low risk; 1-Minimal danger.

The DM evaluates the alternative concerning the scale. Taking this as an example, the DM considers the Financial Score Criterion (FSC), classifies the operation's risk as extreme, high, medium, low, or minimum, indicates the corresponding scale field, and proceeds with the other criteria. The characteristics of the elements of the scale were considered in a continuum between the maximum and the minimum (Fig. 2). It is important to note that this continuum is designed to represent the organization's vision and serves as a guide for DMs. 
The performance table of the twelve alternatives by the three DMs is presented in Table 6.

\section{System}

The development of the sorting model for GDM presented in this paper is based on the precepts defined by the ELECTRE TRI-B classification method. The decision system, as seen in Fig. 1, goes through the definition of the criteria, weights, and preferences that, once established, guide the DMs in their analysis subsequently leading from an

Table 6 Analysis of credit proposals (alternatives) per DM

\begin{tabular}{|c|c|c|c|c|c|c|c|c|c|}
\hline INPUT & DM & $\mathrm{PCP}(\mathrm{g} 1)$ & FSC (g2) & $\mathrm{DCP}(\mathrm{g} 3)$ & $\mathrm{OPH}(\mathrm{g} 4)$ & WOP (g5) & WAN (g6) & PAC (g7) & REL (g8) \\
\hline \multicolumn{10}{|c|}{ Evaluation of proposals by evaluators } \\
\hline \multirow{3}{*}{$\begin{array}{l}\text { Credit proposal } \\
1 \text { (a1) }\end{array}$} & 1 & 4 & 2 & 4 & 1 & 4 & 3 & 2 & 2 \\
\hline & 2 & 3 & 1 & 4 & 1 & 3 & 4 & 2 & 3 \\
\hline & 3 & 4 & 2 & 3 & 1 & 4 & 4 & 2 & 2 \\
\hline \multirow{3}{*}{$\begin{array}{l}\text { Credit proposal } \\
2 \text { (a2) }\end{array}$} & 1 & 1 & 4 & 3 & 4 & 1 & 1 & 2 & 5 \\
\hline & 2 & 2 & 4 & 3 & 4 & 2 & 1 & 2 & 5 \\
\hline & 3 & 1 & 4 & 2 & 4 & 2 & 1 & 2 & 4 \\
\hline \multirow{3}{*}{$\begin{array}{l}\text { Credit proposal } \\
3 \text { (a3) }\end{array}$} & 1 & 2 & 1 & 3 & 3 & 4 & 4 & 3 & 3 \\
\hline & 2 & 3 & 1 & 3 & 3 & 3 & 4 & 4 & 3 \\
\hline & 3 & 3 & 1 & 2 & 3 & 4 & 3 & 4 & 4 \\
\hline \multirow{3}{*}{$\begin{array}{l}\text { Credit proposal } \\
4 \text { (a4) }\end{array}$} & 1 & 5 & 2 & 4 & 5 & 5 & 5 & 3 & 3 \\
\hline & 2 & 4 & 2 & 4 & 4 & 5 & 5 & 3 & 4 \\
\hline & 3 & 4 & 4 & 3 & 5 & 5 & 5 & 4 & 3 \\
\hline \multirow{3}{*}{$\begin{array}{l}\text { Credit proposal } \\
5 \text { (a5) }\end{array}$} & 1 & 4 & 4 & 3 & 4 & 3 & 1 & 2 & 3 \\
\hline & 2 & 4 & 4 & 4 & 4 & 3 & 2 & 2 & 3 \\
\hline & 3 & 3 & 4 & 3 & 4 & 2 & 1 & 2 & 3 \\
\hline \multirow{3}{*}{$\begin{array}{l}\text { Credit proposal } \\
6 \text { (a6) }\end{array}$} & 1 & 2 & 2 & 3 & 4 & 2 & 4 & 3 & 3 \\
\hline & 2 & 2 & 1 & 3 & 4 & 2 & 5 & 2 & 3 \\
\hline & 3 & 3 & 2 & 2 & 4 & 2 & 4 & 2 & 2 \\
\hline \multirow{3}{*}{$\begin{array}{l}\text { Credit proposal } \\
7 \text { (a7) }\end{array}$} & 1 & 2 & 2 & 1 & 2 & 1 & 1 & 2 & 1 \\
\hline & 2 & 2 & 3 & 3 & 2 & 2 & 2 & 2 & 2 \\
\hline & 3 & 2 & 1 & 2 & 2 & 1 & 2 & 2 & 2 \\
\hline \multirow{3}{*}{$\begin{array}{l}\text { Credit proposal } \\
8 \text { (a8) }\end{array}$} & 1 & 2 & 2 & 3 & 2 & 1 & 1 & 2 & 1 \\
\hline & 2 & 2 & 3 & 2 & 1 & 2 & 2 & 2 & 2 \\
\hline & 3 & 3 & 2 & 2 & 2 & 1 & 2 & 2 & 2 \\
\hline \multirow{3}{*}{$\begin{array}{l}\text { Credit proposal } \\
9 \text { (a9) }\end{array}$} & 1 & 5 & 3 & 3 & 3 & 1 & 5 & 1 & 3 \\
\hline & 2 & 5 & 2 & 3 & 4 & 2 & 4 & 1 & 2 \\
\hline & 3 & 5 & 3 & 2 & 4 & 2 & 5 & 2 & 3 \\
\hline \multirow{3}{*}{$\begin{array}{l}\text { Credit proposal } \\
10 \text { (a10) }\end{array}$} & 1 & 5 & 1 & 1 & 2 & 4 & 5 & 1 & 3 \\
\hline & 2 & 4 & 1 & 2 & 2 & 4 & 5 & 2 & 3 \\
\hline & 3 & 4 & 3 & 2 & 2 & 4 & 5 & 2 & 3 \\
\hline \multirow{3}{*}{$\begin{array}{l}\text { Credit proposal } \\
11 \text { (a11) }\end{array}$} & 1 & 1 & 1 & 1 & 1 & 4 & 5 & 1 & 2 \\
\hline & 2 & 2 & 1 & 2 & 2 & 4 & 4 & 2 & 2 \\
\hline & 3 & 3 & 2 & 3 & 2 & 4 & 4 & 2 & 1 \\
\hline \multirow{3}{*}{$\begin{array}{l}\text { Credit proposal } \\
12 \text { (a12) }\end{array}$} & 1 & 1 & 3 & 3 & 1 & 3 & 4 & 2 & 3 \\
\hline & 2 & 1 & 4 & 4 & 2 & 3 & 4 & 2 & 2 \\
\hline & 3 & 1 & 5 & 4 & 1 & 3 & 3 & 2 & 3 \\
\hline
\end{tabular}

Key for criteria: $F S C$ financial score, $D C P$ debt capacity, $P C P$ payment capacity, WAN wealth analysis, $O P H$ operations history, $W O P$ warranty in operation, $P A C$ professional activity, $R E L$ relationship level 
aggregation process and decision rules to a result that classifies the alternative (credit proposal) into defined classes. The organizations work with financial capital loans that must present stable returns while maintaining organizational activities, given that the higher the security of the process, the better it is for the organization. A process can be developed by using the ELECTRE TRI-B method, thereby defining a systematic process that assists decision-making and guarantees that the return will contribute to achieving organizational strategic objectives.

The ELECTRE TRI-B method is presented by Mousseau et al. (2000) as a multicriteria sorting method that assigns alternatives to predefined categories. The assignment of alternative results from comparing an alternative with the limits that define a predefined category. Let $F$ indicate the index set of criteria $g_{1}, g_{2}, \ldots, g_{m}(F=\{1,2, \ldots, m\})$ and $B$ indicate the index set of profiles that define the $p+1$ category $(B=\{1,2 \ldots, P\}), b_{h}$ where the upper limit of category $c_{h}$ and the lower limit of category $c_{h}+1, h=1,2, \ldots, p$. In the following, preferences are assumed to increase with the value in each criterion. In this case, schematically, ELECTRE TRI-B assigns alternatives to categories following two consecutive steps: (1) constructing an outranking relationship $S$ that characterizes how alternatives compare with category boundaries; and (2) exploring the relationship $\mathrm{S}$ to assign each alternative to a specific category. However, some parameters must first be defined as set out in the section below.

\section{Category limits and parameters}

The definition of classes is given by setting lower and upper limits. This concept is exemplified by Cailloux et al. (2012): "We consider a finite set of alternatives $A$, a set of profiles $B=\left\{b_{0}, \ldots b_{k}\right\}$, and a finite set of criteria $\left\{g_{j}, j \in J\right\}$. A criterion $g_{j}, j \in J$, is a function from $A \cup B$ to $R$ where $g_{j}$ (a) denotes the alternative's performance on the criterion $g_{j}$. The alternatives have to be sorted in $\mathrm{k}$ categories $c_{1}, \ldots, c_{k}$, ordered by their desirability $\left(c_{1}\right.$ is the worst category and $c_{k}$ is the best one). Each category $c_{h}$ is defined by the performances of its lower profile $b_{h-1}$ and its upper profile $b_{h}$, with $b_{h-1}, b_{h} \in B$. The performances are meant to be such that a higher value denotes a better performance, and the performances on the profiles are meant to be non-decreasing, that is, $\forall j \in J, 1 \leq h \leq k: g_{j}$ $\left(b_{h-1}\right) \leq g_{j}\left(b_{h}\right)$."

Based on the analysis scale and the organizational strategic objectives, the upper and lower limits of each category were defined for the proposed model, as presented in Fig. 3.

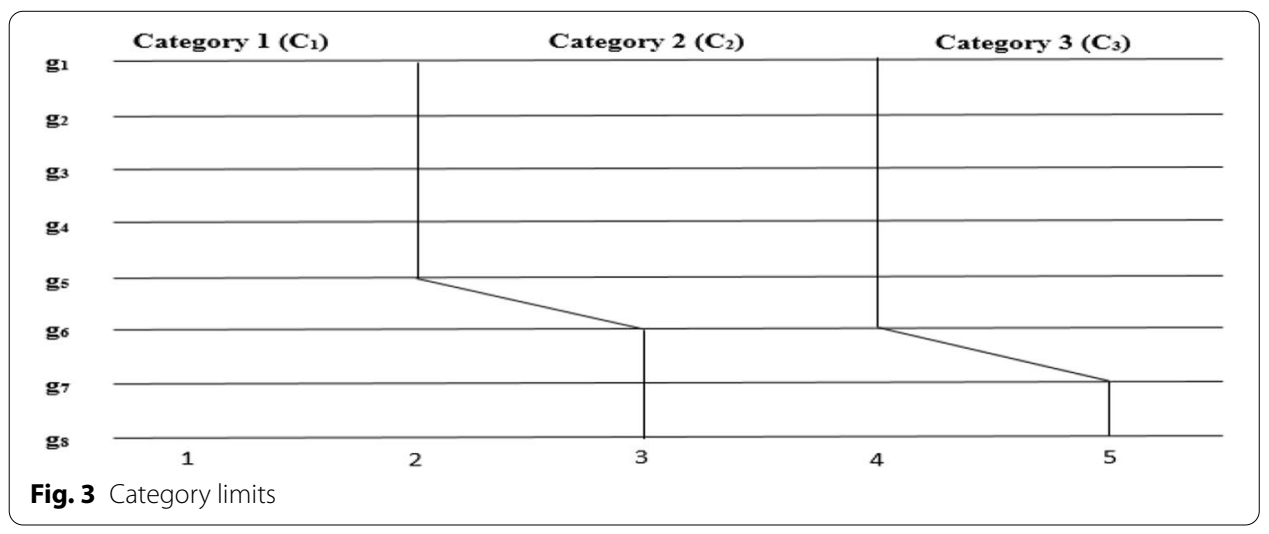


These values are defined by the CEO with the support of the analyst: "credit approved" $\left(\mathrm{C}_{1}\right)$ means that the credit proposal is authorized, "technical analysis" $\left(C_{2}\right)$ means that the credit proposal requires further analysis and some evidentiary documents can be requested, and "credit rejected" $\left(\mathrm{C}_{3}\right)$ means that the credit proposal is refused.

After the thresholds of the categories were established, which consisted of the organization's representative values, the need to develop the preference and indifference limits was analyzed. With regard to the limits of preference and indifference, Roy (1978) presents three distinct thresholds to incorporate the uncertainties inherent in most impact evaluations. For any given environmental criterion, the three thresholds are as follows:

- The indifference threshold, $q$, beneath which the DM is indifferent to two project option valuations;

- The preference threshold, $p$, above which the DM shows a clear, strict preference for one project option

- The veto threshold, $u$, where a discordant difference in favor of one option higher than this value will require the DM to negate any possible outranking relationship indicated by the other criteria. Fixing these thresholds involves significant subjective input by the DM.

The preference $\left(p_{m}\right)$ and indifference $\left(q_{m}\right)$ thresholds were defined by the CEO with the assistance of the analyst and are presented below:

- Preference $\left(p_{m}\right): g_{1}: 2, g_{2}: 2, g_{3}: 2, g_{4}: 2, g_{5}: 2, g_{6}: 3, g_{7}: 3, g_{8}: 3$

- Indifference $\left(q_{m}\right): g_{1}: 0, g_{2}: 0, g_{3}: 0, g_{4}: 0, g_{5}: 0, g_{6}: 0, g_{7}: 0, g_{8}: 0$

Decisions based on the results of the analysis are subject to discrepancies. In this case, when specific situations occur during the examination, one of the component tools of the ELECTRE TRI-B system applies the veto concept.

The veto thresholds used in the discordance test represent the smallest difference incompatible with the $\mathrm{aSb}_{\mathrm{h}}$ assertion (Mousseau et al. 2000, p. 760).

A veto limit will not be used for alternatives. Setting a veto limit would make little sense because, in the case of doubt as to whether the proposal should be approved or sent for technical analysis, the best decision would be to submit it to technical analysis. It is considered that in proposals for which definitions may deserve special attention, such attention would be given through technical analysis, which, after further analysis of the proposer's situation, results in the proposal being approved, rejected, or even new documents or guarantees being requested.

\section{Individual analysis}

Initially, the concordance index $c_{j}(a, b)$ must be determined, according to Eq. 1. The concordance represents the "adequate" concordant coalition of criteria that accepts the assertion " $a$ outranks $b$ "-aSb.

$$
c(a, b h)=\sum_{j \in c(a P b)} w_{j}+\sum_{j \in x(a I b)} w_{j}+\sum_{j \in c(a \mathrm{Q} b)} w_{j}+\sum_{j \in c(a Q b)} \varphi_{j} w_{j}
$$


where $_{\varphi_{j}}=\frac{p_{j}\left(g_{j}(a)-g_{j}(b)\right)}{p_{j}-q_{j}} \in[0,1]^{\circ}$

Moreover, the discordance index $d_{j}(a . b)$ needs to be defined. It represents that no coalition of criteria opposes the assertion $a S b$ too strongly (see Eq. 2). This index is associated with the veto threshold $\left(u_{j}\right)$.

$$
\operatorname{dj}(a, b h)\left(\begin{array}{c}
0 \rightarrow i f g j(a) \leq g j(b h)+p j(b h) \\
1 \rightarrow i f g j(a)>g j(a)+u j(b h) \\
\in 0,1 \text { otherwise }
\end{array}\right)
$$

The credibility index $\sigma(a, b)$ represents the degree that "a outranks b," and it is expressed by Eq. 3 .

$$
\begin{aligned}
& \sigma(a ; b h)=\mathrm{c}(\mathrm{a}, \mathrm{bh}) \prod_{j \in f} \frac{1-d(a, b h)}{1-c(a, b h)} \\
& \text { Where } \bar{F}=\{j \in F: \operatorname{dj}(a, b h)>c(a, b h)\}
\end{aligned}
$$

The accuracy of the analysis depends on a cut-off level $(\lambda)$, the range of which can vary from 0.5 to 1.0. The $\lambda$ value is determined considering the level of rigor that will apply in the credibility analysis. The value 0.76 is the consensus regarding a regular level of rigor. The results are presented in Table 7. Moreover, a sensitivity analysis was applied to confirm the stability of the proposed model. In this analysis, $\lambda$ is the only parameter modified to increase the level of rigor (see Table 7).

According to Table 7, the sensitivity analysis promotes some significant modifications in the outcomes. Therefore, if $\lambda=0.85$, it represents an elevated level of rigor in credibility analysis, and only one alternative should be classified as approved ( $a_{7}$ and

\begin{tabular}{|c|c|c|c|c|c|c|}
\hline \multirow[t]{2}{*}{ Alternatives } & \multicolumn{3}{|c|}{ Scenario $1(\lambda=0.76)$} & \multicolumn{3}{|c|}{ Scenario $2(\lambda=0.85)$} \\
\hline & $\mathrm{DM}_{1}$ & $\mathrm{DM}_{2}$ & $\mathrm{DM}_{3}$ & $\mathrm{DM}_{1}$ & $\mathrm{DM}_{2}$ & $\mathrm{DM}_{3}$ \\
\hline$a_{1}$ & $C_{2}$ & $C_{2}$ & $C_{2}$ & $C_{2}$ & $C_{2}$ & $C_{2}$ \\
\hline$a_{2}$ & $C_{2}$ & $C_{2}$ & $C_{2}$ & $C_{2}$ & $C_{2}$ & $C_{2}$ \\
\hline$a_{3}$ & $C_{2}$ & $C_{2}$ & $C_{2}$ & $C_{2}$ & $C_{2}$ & $C_{2}$ \\
\hline$a_{4}$ & $C_{3}$ & $\mathrm{C}_{2}$ & $C_{2}$ & $C_{3}$ & $C_{2}$ & $C_{3}$ \\
\hline$a_{5}$ & $C_{2}$ & $C_{2}$ & $C_{2}$ & $C_{2}$ & $C_{2}$ & $C_{2}$ \\
\hline$a_{6}$ & $C_{1}$ & $C_{2}$ & $C_{2}$ & $C_{2}$ & $C_{3}$ & $C_{2}$ \\
\hline$a_{7}$ & $C_{1}$ & $C_{1}$ & $C_{1}$ & $C_{1}$ & $C_{1}$ & $C_{1}$ \\
\hline$a_{8}$ & $C_{1}$ & $C_{1}$ & $C_{1}$ & $C_{1}$ & $C_{1}$ & $C_{1}$ \\
\hline$a_{9}$ & $C_{2}$ & $C_{2}$ & $C_{2}$ & $C_{3}$ & $C_{3}$ & $C_{3}$ \\
\hline$a_{10}$ & $C_{2}$ & $C_{2}$ & $C_{2}$ & $C_{3}$ & $C_{3}$ & $C_{3}$ \\
\hline$a_{11}$ & $C_{1}$ & $C_{1}$ & $\mathrm{C}_{2}$ & $C_{3}$ & $\mathrm{C}_{2}$ & $\mathrm{C}_{2}$ \\
\hline$a_{12}$ & $C_{1}$ & $C_{2}$ & $C_{2}$ & $C_{2}$ & $C_{2}$ & $C_{3}$ \\
\hline
\end{tabular}
$a_{8}$ ). This scenario can be used in stable market conditions.

Table 7 Results of the assignments 


\section{Group aggregation}

For a credit proposal to be approved, it must have a simple majority arising from the classification given to it as a result of the DMs' individual analysis. It is worth remembering that this rule may vary according to organizational objectives.

Morais et al. (2014) consider that it is possible to define-with the DM in certain realworld contexts, if necessary-the lowest probability that allows a category to be fixed as the most suitable one. The authors exemplify that, if the index $I>0.75$ (the probability of alternative $a_{i}$ being assigned to $C_{n}$ ) is at least 75\%; the DMs can fix $C_{n}$ as the category that should receive $a_{i}$. Figure 4 shows the author's illustration, which represents the idea of aggregating results that could lead to a conflict or non-conflict situation.

In this proposed model, an individual analysis guided by the specifications of the model leads to classifications that may or may not coincide, leading to the need for rules that lead to the process of decision-making. Operationally, the system defines the aggregation result by checking the decision rules established by the organizations as follows:

- A simple majority of one of the classes = the alternative is classified in that category.

- An alternative with distinct categories means the worst assessment prevails. In this case, the proposal is rejected and returned to the branch, which will then undertake appropriate procedures.

- For $n$ DMs, the decision rule defines that the simple majority wins and, if there is a tie, the pessimistic view is adopted, and the lowest classification wins. The pessimistic view is necessary to provide greater security during operation.

Figure 5 shows that, of the 12 credit proposals analyzed using $\lambda=0.85$, three credit proposals (credit proposals 4, 9, and 10) were rejected, and two credit proposals had direct approval (credit proposals 7, 8). The remaining cases were classified for technical analysis procedures. Figure 5 shows the flow of the analysis process and the aggregation of the results.

The results presented, using the decision rules suggested, at first sight, overload the professional responsible for the technical analysis, which would imply that the organization needs to invest in this sector with more employees or at least provide technological support so that the process becomes agile and efficient.

However, it is worth remembering that the strategic decision rules fall within the organization's competence that can, through further studies, change the decision rule

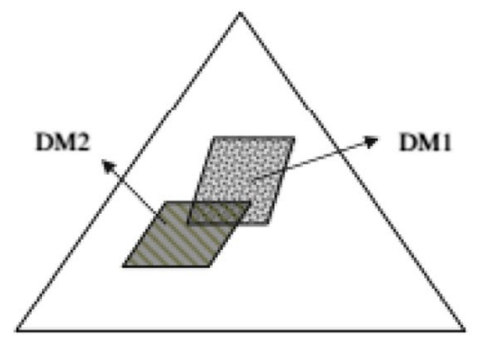

(a) Non-conflict situation

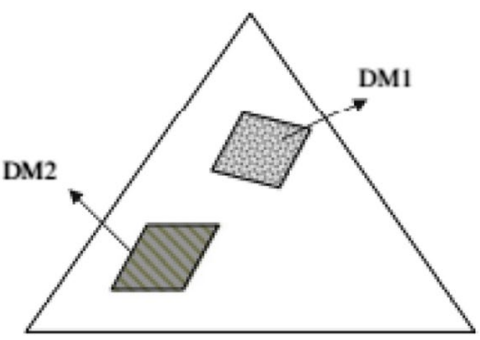

(b) Conflict situation

Fig. 4 Aggregation of results: non-conflict and conflict situation 


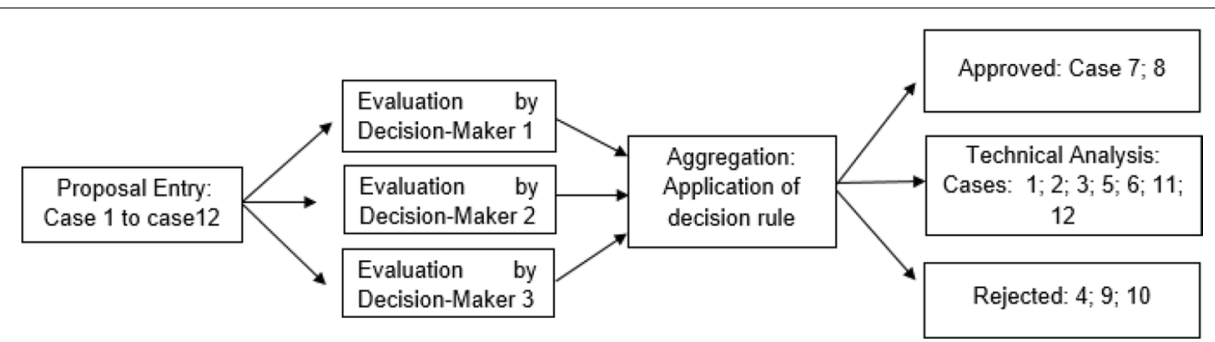

Fig. 5 The flow of the analysis process to the aggregation of the results

without changing the process. If the organization chooses to be more rigid, the number of rejected cases will increase. Suppose the organization decides to relax the decision rule. In that case, it will minimize the effects of referral for technical analysis, leading to a more significant number of direct approvals, which would consequently increase the risk of loss in the process. In any case, the approach is flexible, thus allowing the organization to define the decision rules strategically.

For process security, the organization must train its DMs. This training must be carried out in a continuous manner and cover the strategic and operational aspects of the decision-making process.

\section{Discussion and conclusion}

The initial objective of this study was to develop a methodology for the theoretical formation of decision-making tools applicable in variable environments such as the financial system. The desired method should be consider organizational reality, its strategic objectives, and the implementation of theories oriented toward decisionmaking. The main contribution was the presentation of a strategic vision in the study of decision theories concerned with the formation and pursuit of conscious decisionmaking and focused on achieving organizational goals.

Here, we developed a new credit-granting sorting model for credit analysis in financial organizations based on a group decision, adopting the ELECTRE TRI-B method. A flow diagram of the process was developed. This study proposes a methodology that can serve as a tool for organizations.

The process was developed based on previous studies on methodologies applied to financial institutions and the decision-making process. This study shows that there is a need to understand how organizations can include their strategic objectives within the context of credit analysis decisions based on a methodology that serves decision-making groups. The study focused on understanding the process of decision-making. The development of the approach followed the ELECTRE TRI-B methodology, which was applied to classifying received proposals for borrowing within specific risk classes.

Finally, considering the criteria of use applicable in financial organizations, it was possible not only to develop an approach that reached the objective of inserting strategic organizational goals in the context of the credit analysis decision but also show that the approach contributes significantly to the resolution of corporate conflicts, provides security for the DM, and minimizes the risks of credit-granting operations. 


\section{Practical implications}

The main problem that this new approach solves for an organization is the systematization of the process. It causes the DMs to think about their analysis and its consequences in an organized and directed manner, thereby allowing them to reflect and enable a more secure means of reaching a decision.

Besides, other factors identified as problems of the organization's current system are minimized when using the proposed approach, such as the DM's uncertainty, which is minimized by having a systematic and defined means of analyzing each case. It also renders the emergence of informal groups unfeasible. Each DM should analyze the analysis criteria individually using his/her perceptions; there is no reason for the DMs to discuss them with each other, consequently reducing organizational conflicts. In addition, the fact that informal meetings are unnecessary reduces the possibility of corruption or collusion among members of the analysis committee. Ultimately, because it is a defined process, and each DM has autonomy, the methodology reduces interference in the process. The DM will start his/her analysis independently of any external forces.

Meanwhile, this model's flexibility allows its adaptation to various applications, regardless of the size or location of the organization. All that needs to be done is to re-evaluate the criteria and analyze their importance.

Considering the results from the model and what to do with the proposals once analyzed and with a deferred decision, they follow directions and organizational decisions. Operationally, this is equivalent to following the flow of operations that the organization defines, and may be directed by the following: (1) approved proposals $\left(C_{1}\right)$ going to the service units for signature collection and credit release actions on the applicant; (2) proposals, decisions on which are forwarded for technical analysis $\left(C_{2}\right)$, have their flow directed to a credit analyst, who in turn will make a more in-depth analysis of the information provided by the applicant and decide on whether to recommend approval $\left(C_{1}\right)$ or rejection $\left(C_{3}\right)$ and, once agreed by the technical analyst, the proposal follows the normal flow presented for the categories into which they fall; (3) proposals defined for the rejected category $\left(C_{3}\right)$ will be returned to the service units that must communicate the decision to the applicant. In the case of rejected proposals $\left(C_{3}\right)$, they may re-enter the system as a new proposal, if the proposer submits further information or guarantees.

Finally, when the credit-granting sorting model for financial organizations is implemented, it will help to facilitate operations and offer more security in credit operations, thereby giving more confidence that the invested capital will result in a return in the expected terms and conditions, thus generating a competitive gain, and, consequently, achieving strategic organizational objectives.

Given these benefits, it is worth mentioning the difficulties and barriers that can hinder the implementation of the model or even make the model's functionality impossible if not well worked out. The first barrier is organizational culture. For the model to be effective, corporate culture must be strategically applied proactively. If the organization is not yet prepared to receive the model, convincing presentations should be conducted to prepare the organization for using the model.

The second barrier is the engagement and preparation of DMs. For the success of the model, DMs must be committed and involved in the process. This commitment can 
come through personnel development activities, including training on operationalities, objectives, and even the strategic organizational role.

The third barrier to implementing the model is the possible conflict with the organization's strategic decisions and the adopted criteria. The importance of an organization's strategic role is highlighted to solve this problem. It defends the idea that the model applies to proactive strategic organizations. Once so, the definition of the criteria to be adopted will be carefully considered and compared with the organization's long-term objectives. In this same line of thought, once the application of the model is defined, it must meet the long-term strategic objectives of the organization, and the result of the process must be organizational policy, overlapping other goals that, for now, may question this decision from a strategic point of view. Changes in the criteria and parameters of the model are possible, which leads to the need for a strategic review in pre-defined periods of turbulence in the market, thus ensuring that the model always follows strategic thinking.

The fourth and final possible barrier to implementing the model is the emergence of new external or internal variables that affect strategic organizational thinking. In the case of environmental situations or changes that affect the organization in its business, further reflection on the model must be coordinated, leading, as stated, to the adaptation and guarantee that the model always follows the company's long-term objectives.

\section{Theoretical contributions}

While previous studies focus on the decision-making process by using multicriteria methods in financial activities, this article offers an insight into how strategic organizational objectives can be implemented in a group credit analysis process. It was observed that the nature of decisions in the financial arena requires different models, as the operational process can occur both in the individual sphere and in group settings.

This article theoretically contributes to the literature as a tool that considers the essential expectations of an economic environment aimed at obtaining results in the decisionmaking process. In practice, this article helps financial organizations to conduct the credit analysis process using a multicriteria method.

By applying the ELECTRE TRI-B multicriteria approach, this analysis shows that it is possible to execute the proposed model within the credit analysis system operated by a decision-making group. This strategic direction helps to meet the significant objectives of the institution. This process is evident when addressing the organization's strategic goals and implementing them within a system to offer guidance for a decision-making group. The methodology was prepared for this purpose, offering more security to DMs when they make decisions.

\section{Limitations and future research}

The model presented for credit granting seeks to find solutions to real problems detected in the organizational environment. This study's limitations include many aspects that influence this environment, including legal, cultural, and technological variables. Another limitation is that individuals' behavioral characteristics and how organizations select and prepare people to play decision-making roles were not studied. 
This study is not an end in itself, as the application of this method might prompt new sequential studies, involving new variables and applications for organizations. Many studies could be conducted based on the contributions of this study, such as identifying, within a behavioral context, the extent to which people are engaged in the decision-making process and the extent to which DMs are willing to undergo professional development to understand the strategic aspects of the organization. A research strand can be defined to study how organizations select and prepare members of decision-making groups to exercise this role in the context of credit analysis.

Another study that could grow from this model is analyzing how organizations develop their strategic objectives and are concerned with this interconnection in the decision-making process. The definitions of organizational strategies are varied, and each organization can identify ways to link its strategy to its operations. Understanding the variability in defining strategies, how administrative systems are maintained, and how they affect the decision-making process can elucidate further theories focused on corporate practices.

This article also presents the operational process of the method, but no software or computer system was developed for application in organizations. Such software development can be considered in future studies.

Finally, other models for GDM can be developed to complement the present work, either by applying the methodology used or implementing other multicriteria methods of decision-making that meet the sorting problem.

\section{Abbreviations}

CEO: Chief Executive Officer; DCP: Debt capacity; DM: Decision-maker; FSC: Financial score; OPH: Operations history; PAC: Professional activity; PCP: Payment capacity; REL: Relationship level; SRF: Simos-Roy-Figueira; WAN: Wealth analysis; WOP: Warranty in operation.

Acknowledgements

The authors are grateful for the Brazilian Research Council (CNPq) funding and the National Council for the Improvement of Higher Education (CAPES) to support this paper's research.

\section{Authors' contributions}

PCS contributed with the application of research and discussion of content with the organization. PCS, LSP and DCM contributed to the development of the text, interpretation of data and formatting of the research. All authors have read and approved the final version of the manuscript.

Funding

Brazilian Research Council (CNPq)_Process: 309143/2014-4.

Availability of data and materials

The data used for analysis and research findings are presented in the tables of the article itself. Complementary data can not be made available due to legal and confidentiality issues, guided by the research organization.

\section{Declarations}

Competing interests

The authors declare that they have no competing interests.

Received: 23 December 2020 Accepted: 14 November 2021

Published online: 01 February 2022

\section{References}

Alhassany H, Faisal F (2018) Factors influencing the internet banking adoption decision in North Cyprus: an evidence from the partial least square approach of the structural equation modeling. Financ Innov 4:29. https://doi.org/10. 1186/s40854-018-0111-3 
Angilella S, Mazzù S (2015) The financing of innovative SMEs: a multicriteria credit rating model. Eur J Oper Res 244(2):540-554. https://doi.org/10.1016/j.ejor.2015.01.033

Arthur KNA (2017) Financial innovation and its governance. Cases of two major innovations in the financial sector. Financ Innov 3:10. https://doi.org/10.1186/s40854-017-0060-2

Asongu SA, Nwachukwu JC (2017) At what levels of financial development does information sharing matter? Financ Innov 3:11. https://doi.org/10.1186/s40854-017-0061-1

Baucells M, Sarin RK (2003) Group decisions with multiple criteria. Manag Sci 49(8):1 105-1118. https://doi.org/10.1287/ mnsc.49.8.1105.16400

Bohanec M (2009) Decision making: a computer-science and information-technology viewpoint. Interdiscip Descr Complex Syst 7(2):22-37

Bouyssou D, Marchant T (2015) On the relations between ELECTRE TRI-B and ELECTRE TRIC and on a new variant of ELECTRE TRI-B. Eur J Oper Res 242(1):201-211

Cabrerizo FJ, Herrera-Viedma E, Pedryc W (2013) A method based on PSO and granular computing of linguistic information to solve group decision-making problems defined in heterogeneous contexts. Eur J Oper Res 230(3):624-633. https://doi.org/10.1016/j.ejor.2013.04.046

Cailloux O, Meyer P, Mousseau V (2012) Eliciting ELECTRE TRI category limits for a group decision-makers. Eur J Oper Res 233(1):133-140. https://doi.org/10.1016/j.ejor.2012.05.032

Çalı S, Balaman ŞY (2019) A novel outranking based multicriteria group decision-making methodology integrating ELECTRE and VIKOR under intuitionistic fuzzy environment. Expert Syst Appl 119:36-50. https://doi.org/10.1016/j. eswa.2018.10.039

Chavira DAG, Lopez JCL, Noriega JJS, Valenzuela OA, Carrillo PAA (2017) A credit ranking model for a parafinancial company based on the ELECTRE-III method and a multiobjective evolutionary algorithm. Appl Soft Comput 60:190-201. https://doi.org/10.1016/j.asoc.2017.06.021

Chen Z, Li Y, Wu Y et al (2017) The transition from traditional banking to mobile internet finance: an organizational innovation perspective-a comparative study of Citibank and ICBC. Financ Innov 3:12. https://doi.org/10.1186/ s40854-017-062-0

Cleofas-Sánchez L, García V, Marqués Al, Sánchez JS (2016) Financial distress prediction using the hybrid associative memory with translation. Appl Soft Comput 44:144-152. https://doi.org/10.1016/j.asoc.2016.04.005

Corrente S, Doumpos M, Greco S et al (2017) Multiple criteria hierarchy process for sorting problems based on ordinal regression with additive value functions. Ann Oper Res 251:117-139. https://doi.org/10.1007/s 10479-015-1898-1

Dembczynski K, Kotlowski W, Slowinski R (2007) Ordinal classification with decision rules. In: The 18th European conference on machine learning and the 11 th European conference on principles and practice of knowledge discovery in databases. Springer, Berlin. https://doi.org/10.1007/978-3-540-68416-9_14

Dias LC, Mousseau V (2018) Eliciting multi-criteria preferences: ELECTRE models. In: Dias L, Morton A, Quigley J (eds) Elicitation international series in operations research \& management science, vol 261. Springer, Cham. https://doi. org/10.1007/978-3-319-65052-4_14

Doumpos M, Figueira JR (2019) A multicriteria outranking approach for modeling corporate credit ratings: an application of Electre Tri-nC method. Omega 82:166-180. https://doi.org/10.1016/j.omega.2018.01.003

Doumpos M, Zopounidis C (2010) A multicriteria decision support system for bank rating. Decis Support Syst 40(1):5563. https://doi.org/10.1016/j.dss.2010.07.002

Elbanna S, Child J (2007) The Influence of decision, environmental and firm characteristics on the rationality of strategic decision-making. J Manag Stud 44(4):561-591. https://doi.org/10.1111/j.1467-6486.2006.00670.x

Figueira J, Roy B (2002) Determining the weights of criteria in the ELECTRE type methods with a revised Simos' procedure. Eur J Oper Res 139(2.1):317-326. https://doi.org/10.1016/S0377-2217(01)00370-8

Figueira JR, Greco S, Roy B, Słowiński R (2013) An overview of ELECTRE methods and their recent extensions. J MultiCriteria Decis Anal 20:61-85. https://doi.org/10.1002/mcda.1482

Gaganis C, Papadimitri P, Tasiou M (2020) A multicriteria decision support tool for modeling bank credit ratings. Ann Oper Res. https://doi.org/10.1007/s10479-020-03516-9

Garcia F, Guijarro F, Moya I (2013) Monitoring credit risk in the social economy sector by means of a binary goal programming model. Serv Bus 7:483-495. https://doi.org/10.1007/s11628-012-0173-7

García V, Sánchez JS, Marqués Al (2019) Synergetic application of multi-criteria decision-making models to credit granting decision problems. Appl Sci 9(23):5052. https://doi.org/10.3390/app9235052

Garrido E, Gomez J, Maicas JP, Orcos R (2014) The institution-based view of strategy: how to measure it. BRQ 17(2):82101. https://doi.org/10.1016/j.brq.2013.11.001

Govindan K, Jepsen MB (2016) ELECTRE: a comprehensive literature review on methodologies and applications. Eur J Oper Res 250(1):1-29. https://doi.org/10.1016/j.ejor.2015.07.019

Guerras-Martín LÁ, Madhok A, Montoro-Sánchez Á (2014) The evolution of strategic management research: recent trends and current directions. BRQ 17(2):69-76. https://doi.org/10.1016/j.brq.2014.03.001

Guo M, Liao X, Liu J (2019) A progressive sorting approach for multiple criteria decision aiding in the presence of nonmonotonic preferences. Expert Syst Appl 123:1-17. https://doi.org/10.1016/j.eswa.2019.01.033

Hamdi J, Hakimi A, Zaghdoudi K (2017) Diversification, bank performance, and risk: have Tunisian banks adopted the new business model? Financ Innov 3:22. https://doi.org/10.1186/s40854-017-0069-6

Hochbaum DS, Levin A (2006) Methodologies and algorithms for group-rankings decision. Manag Sci 52(9):1394-1408. https://doi.org/10.1287/mnsc.1060.0540

Høyland K, Wallace SW (2001) Generating scenario trees for multistage decision problems. Manag Sci 47(2):295-307. https://doi.org/10.1287/mnsc.47.2.295.9834

Hwang CL, Lin MJ (2012) Group decision making under multiple criteria: methods and applications. Springer, Berlin. https://doi.org/10.1007/978-3-642-61580-1

Kadzinki M, Martyn M (2020) Enriched preference modeling and robustness analysis for the ELECTRE Tri-B method. Ann Oper Res. https://doi.org/10.1007/s10479-020-03833-z 
Kashig M, Iftikhar SF, Iftikhar K (2016) Loan growth and bank solvency: evidence from the Pakistani banking sector. Financ Innov 2:22. https://doi.org/10.1186/s40854-016-0043-8

Kautonen T, Fredriksson A, Minniti M, Moro A (2020) Trust-based banking and SMEs' access to credit. J Bus Ventur Insights 14:e00191. https://doi.org/10.1016/j.jbvi.2020.e00191

Khraisha T, Arthur K (2018) Can we have a general theory of financial innovation processes? A conceptual review. Financ Innov 4:4. https://doi.org/10.1186/s40854-018-0088-y

Klapper L, Lusardi A (2019) Financial literacy and financial resilience: evidence from around the world. Financ Manage 9:1-26. https://doi.org/10.1111/fima.12283

Koksalmis E, Kabak Ö (2019) Deriving decision makers'weights in group decision making: an overview of objective methods. Inf Fusion 49:146-160. https://doi.org/10.1016/j.inffus.2018.11.009

Kou G, Xu Y, Peng Y et al (2021) Bankruptcy prediction for SMEs using transactional data and two-stage multiobjective feature selection. Decis Support Syst 140:113429. https://doi.org/10.1016/j.dss.2020.113429

Lin Z, Whinston AB, Fan S (2015) Harnessing Internet finance with innovative cyber credit management. Financ Innov 1:5. https://doi.org/10.1186/s40854-015-004-7

Marqués A, Garcia V, Sánchez JS (2013) A literature review on the application of evolutionary computing to credit scoring. J Oper Res Soc 64:1384. https://doi.org/10.1057/jors.2012.145

Marqués Al, García V, Sánchez JS (2020) Ranking-based MCDM models in financial management applications: analysis and emerging challenges. Prog Artif Intell 9:171-193. https://doi.org/10.1007/s13748-020-00207-1

Moradi S, Rafiei FM (2019) A dynamic credit risk assessment model with data mining techniques: evidence from Iranian banks. Financ Innov 5:15. https://doi.org/10.1186/s40854-019-0121-9

Morais DC, de Almeida AT, Figueira JR (2014) A Sorting model for group decision making: a case study of water losses in Brazil. Group Decis Negot 23:937-960. https://doi.org/10.1007/s10726-012-9321-7

Mousseau V, Slowinski R (1999) Inferring an ELECTRE TRI model from assignment examples. J Glob Optim 12:157-174. https://doi.org/10.1023/A:1008210427517

Mousseau V, Slowinski R, Zielniewicz P (2000) ELECTRE TRI A user-oriented implementation of the ELECTRE TRI method integrating preference elicitation support. Comput Oper Res 27:757-777. https://doi.org/10.1016/50305-0548(99) 00117-3

Nutt PC (1998) How decision makers evaluate alternatives and the influence of complexity. Manag Sci 44(8):1148-1166. https://doi.org/10.1287/mnsc.44.8.1148

Palazuelos E, Herrero Crespo Á, del Corte JM (2018) Effect of perceived default risk and accounting information quality on the decision to grant credit to SMEs. Risk Manag 20:121-141. https://doi.org/10.1057/s41283-017-0030-z

Palazuelos E, Herrero Crespo Á, del Corte JM (2020) Auditing and credit granting to SMEs: an integrative perceptual model. Manag Audit J 35(1):152-174. https://doi.org/10.1108/MAJ-12-2018-2118

Parrino R, Poteshman AM, Weisbach MS (2005) Measuring investment distortions when risk-averse managers decide whether to undertake risky projects. Financ Manag 34:21-60. https://doi.org/10.1111/j.1755-053X.2005.tb00091.X

Pérez IJ, Cabrerizo FJ, Alonso S, Dong YC, Chiclana F, Herrera-Viedma E (2018) On dynamic consensus processes in group decision making problems. Inf Sci 459:20-35. https://doi.org/10.1016/j.ins.2018.05.017

Pérez-Aróstegui MN, Bustinza-Sánchez F, Barrales-Molina V (2015) Exploring the relationship between information technology competence and quality management. BRQ 18(1):4-17. https://doi.org/10.1016/j.brq.2013.11.003

Pla-Santamaria D, Bravo M, Reig-Mullor J, Salas-Molina F (2020) A multicriteria approach to manage credit risk under strict uncertainty. TOP. https://doi.org/10.1007/s11750-020-00571-0

Rehman ZU, Muhammad N, Sarwar B et al (2019) Impact of risk management strategies on the credit risk faced by commercial banks of Balochistan. Financ Innov 5:44. https://doi.org/10.1186/s40854-019-0159-8

Rigopoulos G, Anagnostopoulos K (2010) Fuzzy multicriteria assignment for nominal classification. Methodology and application in evaluation of Greek Bank's electronic payment retailers. Int J Inf Technol Decis Mak 9(3):437-454. https://doi.org/10.1142/s0219622010003890

Roy B (1978) ELECTRE III: Un alghoritme de methode de classements fonde sur une representation floue des préférences em presence de critères multiples. Cahieres De CERO 20(1):3-24

Roy B, Bouyssou D (1993) Aide Multicritère à la Décision: Méthodes et Cas. Economica, Paris

Roy B, Slowiński R (2013) Questions guiding the choice of a multicriteria decision aiding method. Euro J Decis Process 1:69-97. https://doi.org/10.1007/s40070-013-004-7

Saaty TL (2013) The modern science of multicriteria decision making and its practical applications: the AHP/ANP approach. Oper Res 61(5):1101-1118. https://doi.org/10.1287/opre.2013.1197

Schäfermeyer M, Rosenkranz C, Holten R (2012) The impact of business process complexity on business process standardization. Bus Inf Syst Eng 4:261. https://doi.org/10.1007/s12599-012-0224-6

Schotten PC, Morais DC (2019) A group decision model for credit granting in the financial market. Financ Innov. https:// doi.org/10.1186/s40854-019-0126-4

Shen F, Zhao X, Kou G (2020) Three-stage reject inference learning framework for credit scoring using unsupervised transfer learning and three-way decision theory. Decis Support Syst 137:113366. https://doi.org/10.1016/j.dss.2020. 113366

Spronk J, Steuer RE, Zopounidis C (2016) Multicriteria decision aid/analysis in finance. In: Greco S, Ehrgott M, Figueira J (eds) Multiple criteria decision analysis international series in operations research \& management science, vol 233. Springer, New York. https://doi.org/10.1007/978-1-4939-3094-4_24

Tsoury A, Soffer P, Reinhartz-Berger I (2019) Data impact analysis in business processes automatic support and practical implications. Bus Inf Syst Eng. https://doi.org/10.1007/s12599-019-00611-5

Ulucan A, Atici KB (2013) A multiple criteria sorting methodology with multiple classification criteria and an application to country risk evaluation. Technol Econ Dev Econ 19(1):93-124. https://doi.org/10.3846/20294913.2012.763070

Wang H, Kou G, Peng Y (2021) Multi-class misclassification cost matrix for credit ratings in peer-to-peer lending. J Oper Res Soc 72(4):923-934. https://doi.org/10.1080/01605682.2019.1705193

Wu W, Kou G (2016) A group consensus model for evaluating real estate investment alternatives. Financ Innov 2:8. https://doi.org/10.1186/s40854-016-0027-8 
Zavadskas EK, Turskis Z (2011) Multiple Criteria Decision Making (MCDM) methods in economics: an overview. Technol Econ Dev Econ 17:397-427. https://doi.org/10.3846/20294913.2011.593291

Zhang L, Hu H, Zhang D (2015) A credit risk assessment model based on SVM for small and medium enterprises in supply chain finance. Financ Innov 1:14. https://doi.org/10.1186/s40854-015-0014-5

Zheng J, Takougang SAM, Mousseau V, Pirlot M (2014) Learning criteria weights of an optimistic Electre Tri sorting rule. Comput Oper Res 49:28-40. https://doi.org/10.1016/j.cor.2014.03.012

Zopounidis C, Dimitras AI (1998) ELECTRE TRI method and business failure prediction. In: Zopounidis C, Dimitras Al (eds) Multicriteria decision aid methods for the prediction of business failure. Applied optimization, vol 12. Springer, Boston. https://doi.org/10.1007/978-1-4757-2885-9_3

Zopounidis C, Doumpos M (2002) Multi-criteria decision aid in financial decision making: methodologies and literature review. J Multi-Criteria Decis Anal 11:167-186. https://doi.org/10.1002/mcda.333

Zopounidis C, Doumpos M (2013) Multicriteria decision systems for financial problems. TOP 21:241-261. https://doi.org/ 10.1007/s11750-013-0279-7

Zopounidis C, Galariotis E, Doumpos M, Sarri S, Andriosopoulos K (2015) Multiple criteria decision aiding for finance: an updated bibliographic survey. Eur J Oper Res 247(2):339-348. https://doi.org/10.1016/j.ejor.2015.05.032

\section{Publisher's Note}

Springer Nature remains neutral with regard to jurisdictional claims in published maps and institutional affiliations.

\section{Submit your manuscript to a SpringerOpen ${ }^{\circ}$} journal and benefit from:

- Convenient online submission

Rigorous peer review

Open access: articles freely available online

- High visibility within the field

Retaining the copyright to your article

Submit your next manuscript at $\boldsymbol{\Delta}$ springeropen.com 